although with one exception the rose hybrids were the only ones that were extremely valuable. This was the Carman Gooseberry. Here was a gooseberry that might have revolutionized gooseberry growing since in a limited test it was mildew proof, but unfortunately the seed firm to which it was sold was unable to propagate it.

The roses were perhaps the real attraction of the "Rural Grounds." The Rosa rugosa of Japan was the foundation stock, and upon it were crossed first the Austrian hardy yellow rose known as Harrison's Yellow, then Hybrid Perpetuals and afterwards $\mathrm{Hy}-$ brid Teas. From these crosses hundreds of plants were raised-most of them, of course, worthless, but some of remarkable beauty. From the first cross mentioned came the Agnes Emily Carman, a fine, hardy, longlived, though thorny variety. In color it was like the Jacqueminot, but many times as profuse in blossoming. From other crosses came procumbent roses, hedge roses, tea roses, etc., etc. They did not attain pre-eminence as did the potato varieties but they helped and still help to brighten many a flower garden.
Elbert S. Carman was born on November 30, 1836, in Hempstead, Long Island. He entered Brown University in 1854 , rooming with John Hay. He was obliged to withdraw after two years of work, however, on account of illness. In 1873, he married Agnes E. Brown, by whom he had two children. Immediately after his marriage he moved to River Edge, N. J., where he began to plant and experiment on the place that afterward became so well known as the "Rural Grounds." While here he became so interested in Moore's Rural New-Yorker as a contributor, that he purchased the paper and became its editor in 1876. Through an absolutely open and honest policy, he made this journal a power in the agricultural world. For many years it has stood out against all frauds and impostures to the farmer, even though this went against its monetary interests. Mr. Carman died February 28, 1900, regretted by the many friends he had made in his editorial capacity, who wrote of him like the hero of Leigh Hunt's ever popular poem, "as one who loved his fellow men."

\title{
The Chromosome Hypothesis of Heredity
}

A working hypothesis of some sort is an essential tool of an advancing branch of experimental science. It behooves us in the study of heredity to use the best hypothesis we have, until it is replaced by a better.

The chief cbjections to the chromosome hypothesis, so far as I can gather them, are:

1. The English pioneer, Bateson, used instead the working hypothesis of somatic segregation.

2. The chromosome hypothesis does not appeal to physiologists and chemists.

3 . The affairs of the chromcsomes may be regarded as a consequence instead of as a cause.

4. Many of the changes of chromosomes and nucleus are still uncertain.

5. The chromosome hypothesis was discredited by Weismann's extensive and untested speculations

On the other hand, there are advantages in the use of the chromosome hypothesis.

1. Batsson's counter hypothesis of somatic segregation has proved barren, and appears to be contradicted by certain facts.

2. Sirasburger's unrivalled experience found the chromosome hypothesis to fit the facts of plant cytology as well as those of inheritance.

3. The chromosome hypothesis fits the breeding facts of the Cambridge school even better than their own hypothesis.

4. It has been used as a fertile working hypothesis by Morgan and his fellow-workers in their unique experiments at Columbia University.

5. It seems to be coming more and more into use in accounts of research in plant breeding. It has, I think, no serious rival. Whether we like it or not, it appears to be here to stay.

It must be remembered that an experimenter does not usually question whether the hypothesis he uses is true or false, but whether it is useful or barren in leading to new experiments or connecting up facts. Working with it will soon show whether it is good or bad.

Joh: Bellixg, Florida Agricultural Experiment Station. 